\title{
Factors Influencing the Motivation of Sports Coaches in the Organization and Management of Sports Competition in Owerri Municipal Council of Imo State
}

\author{
Zephy Godfrey Okoro ${ }^{1}$, Zakariya Mohammed Nayawo ${ }^{\mathbf{1}}$, Mukhtar Alhaji Mohammed ${ }^{\mathbf{1}}$, \\ Bitrus Musa ${ }^{2}$ \\ ${ }^{1}$ Department of Physical and Health Education, Faculty of Education, University of Maiduguri, Borno State, Nigeria \\ ${ }^{2}$ Department of Physical and Health Education, Faculty of Education, University of Jos, Plateau State, Nigeria
}

Email address:

mmmuhktar01@gmail.com (Z. M. Nayawo)

\section{To cite this article:}

Zephy Godfrey Okoro, Zakariya Mohammed Nayawo, Mukhtar Alhaji Mohammed, Bitrus Musa. Factors Influencing the Motivation of Sports Coaches in the Organization and Management of Sports Competition in Owerri Municipal Council of Imo State. American Journal of Sports Science. Vol. 4, No. 2, 2016, pp. 38-42. doi: 10.11648/j.ajss.20160402.13

Received: January 7, 2016; Accepted: February 9, 2016; Published: March 22, 2016

\begin{abstract}
This study determined factors influencing the motivation of sports coaches in the organization and management of sports competition on concerned municipal council Imo state. This is so because there can be little doubt that sport coaching has been accorded an increased level of significance in recent years but coaches complained murmuring acted both as a culmination of this attention as reference point for current research and development. Four objectives and four research questions guided the study. The target population for the study comprised of all coaches of Owerri Municipal Council of Imo State. Sample of forty four (44) coaches were selected and used through simple random sampling technique. The instrument used for the study was a structured questionnaire to collect data. Result showed that remuneration, more courses, adequate facilities with standard equipment in-service training and education are factors influencing the motivation of sports coaches. It was recommended among others that provision of grant scheme, scholarship scheme, general promotion of coaching and a comprehensive education system essential but effort to create and support a positive working environment for coaches must be a long term priority.
\end{abstract}

Keywords: Remuneration, Training, Facilities and Equipment, Motivation, Sport Coaches

\section{Introduction}

There can be little doubt that coaching has been accorded an increased level of significance in recent years. The publication of coaching matters (coaching review panel, 1991) acted both culmination of this attention as reference point for current research and development. The contribution of coaches and coaching to the level of sports participation has been recognized (National Coaching Foundation, 1993). The essential contribution to the development of excellence in sports is widely acknowledged (Dept of National Heritage, 1995, Imo State Sports Council after KADA, 2009). A major concern for policy makers, therefore, is an adequate supply of qualified coaches who are not available to increase participation and raise standards in sport (Adenuyi, in
Nigerian Television Authority Nationwide Sports Report, 2009). Motivation comes from the word motive, which are desire to attain certain goals. It is believed that the stronger these desire are present in an individual the greater will be the effort towards achieving the goals. For the coach to perform well, there must be something inside as well as outside them which encourages and pushes them to present the best of their ability. These intrinsic and extrinsic satisfies the coaches each time with what they are doing. It give them special energy, a feeling of contentment, warmth and willingness to work to their highest level of performance and excellence.

Okoye (1987) identified motivation as a process by which an organism disequilibrated by environment contingencies, develops an inner drive geared towards restoring the organizers to a state of equilibrium in a homeostatic manner. 
Similarly, Vallerand and Thrill (1993) stated that motivation is a concept described as the hypothetical constructs used to described the internal and / or external force that produce the initiation, direction, intensity and persistence of behaviours. In support of this, Deci and Ryan (2002), emphasizes the distinction between behaviour driven intrinsically for the innately derived motives of interest, fun, enjoyment, challenge and those driven extrinsically by factors such as rewards, external gain or material gain.

Singer (1997) opined that motivation is anything or condition which initiates, guides, maintains, increases or reduces behaviour or the enthusiasm of an individual's levels of activity. Motivation actually means the energization and direction of behaviour. It is thought to energies behaviour just as coal energize a furnace (Weiner, 1992). Generally, motivation may be seen as a desire by the individual to behave in such away to satisfy a need or to engage in goal seeking behaviour which can arouse to action (Butt, 1974). This motivation occurs when coach / athletes experience incompetence and lack of control. This is typical when athletes feel they lost control of the ability to obtain the desire results of training. This loss of control initiates feelings of helplessness (Chantal, Guay, Debreva and Vallerand, 1996).

According to Miller (1974) a coach sometimes becomes an instructor in the after school sports programme, as the performer is learning at one time or the other, no matter how highly skilled. A coach is someone who specialized in a particular sports and so be appointed to take charge of the sports in an establishment or an institution. Coaches are, therefore, found working in secondary schools, teachers colleges, technical colleges and Universities as well as in sports councils, commissions and clubs (Bucher \& Thaxton, 1981).

Opatola (1999) identified two kinds of coach exist; A professional coach and para-coach. A professional coach is a trained coach who has a basic knowledge in most of the following academic areas, human anatomy and physiology, exercise physiology, kinesiology, Biomechanics, relationship between work and fatigue, human development knowledge and teaching and coaching skills. Therefore, motivation plays a significant role in producing high working climate and spirit for the coaches (Charbonneau, Barlin and Kelloway, 2001). According to Hansen, Gilbert and Hamel (2003). Perisgard and Roberts (2002) and Turman (2005) that motivated coaches face the challenges of balancing criticism and encouragement as well as performance and enjoyment. Coaches use various motivational strategies receiving including direct positive reinforcement, verbally challenging behaviour and physically challenging athletes (Hansen et al., 2003).

Successful application of motivation techniques by any sports administrator depends upon his knowledge of factors that affect motivation, understanding of strategies to motivate coach and the relative effectiveness of each of them in motivating individuals. According to Longe (2008), the remuneration and condition of service also affect occupation.
The amount of capital available to a worker determines the volume of production. The greater the amount of capital available the higher the commitment of the employee. Similarly, Nwachukwu (2007) opined that a satisfied employee has a better attitude to work than a dissatisfied employee. No effort should be sparing by management to ensure that remuneration necessary for the sports coaches are made available.

\section{Methodology}

This study determined factors influencing the motivation of sports coaches in the organization and management of sports competition in Owerri, Municipal Council of Imo state. The target population for this study comprised all sports coaches in Imo state sports council. A sample of 44 coaches were selected and used in the study. The instrument used for data collection was a self-developed questionnaire which were divided into two sections (Sections A and B). Section ' $A$ ' comprised of personal data of respondents, while section ' $\mathrm{B}$ ' deals on factors influencing the motivation of sports coaches of Owerri municipal council. The questionnaire contained fourteen (14) item statements with the response mode of 'Yes' or 'No' were used for the study. The data collected were subjected to frequency counts and its equivalence percentage scores to describe the demographic information and answer researcher questions and was presented in a tabular form for discussion below:

\section{Results}

Table 1. Demographic information of the respondents $(n=44)$.

\begin{tabular}{|c|c|c|c|c|}
\hline $\mathbf{S} / \mathbf{N}$ & Items & Responses & Respondents & Percentage (\%) \\
\hline \multirow{4}{*}{1} & \multirow{4}{*}{ Age } & Below 25 years & 5 & 11.4 \\
\hline & & $25-30$ years & 7 & 15.9 \\
\hline & & $31-36$ years & 15 & 34.1 \\
\hline & & 37 years and above & 17 & 38.6 \\
\hline \multirow{2}{*}{2} & \multirow{2}{*}{$\begin{array}{l}\text { Marital } \\
\text { status }\end{array}$} & Married & 29 & 65.9 \\
\hline & & Single & 15 & 34.1 \\
\hline \multirow{2}{*}{3} & \multirow{2}{*}{ Gender } & Male & 31 & 70.5 \\
\hline & & Female & 13 & 29.5 \\
\hline \multirow{4}{*}{4} & \multirow{4}{*}{$\begin{array}{l}\text { Coaches } \\
\text { status }\end{array}$} & Grade I & 16 & 36.3 \\
\hline & & Grade II & 8 & 18.2 \\
\hline & & Grade III & 8 & 18.2 \\
\hline & & Para-Coach & 12 & 27.3 \\
\hline \multirow{3}{*}{5} & \multirow{3}{*}{$\begin{array}{l}\text { Type of } \\
\text { sports } \\
\text { coached }\end{array}$} & Team Sports & 24 & 54.6 \\
\hline & & Dual Sports & 6 & 13.6 \\
\hline & & Individual Sports & 14 & 31.8 \\
\hline
\end{tabular}

Table 1 above showed that the respondents were 44 where $5(11.4 \%)$ were below the ages of 25 years, $7(15.9 \%)$ of the respondents also fall within the ages of $25-30$ years. Similarly in the same table 1 respondents representing $(34.1 \%)$ were between the ages of $31-36$ years. While 17 $(38.7 \%)$ of the respondents falls within the age of 37 years and above. The table also shows that $29(65.9 \%)$ of the respondents are married while $15(34.1 \%)$ are single. So also $31(70.5 \%)$ of the respondents were male and female 13 $(29.5 \%)$ falls under female. 
Table 2. Respondents' views on remuneration as a factor for influencing motivation of coaches in the organization and management of sports competition $(n=44)$.

\begin{tabular}{llll}
\hline Items/statements & Respondents & Response & Percentage (\%) \\
\hline $\begin{array}{l}\text { Do sports coaches } \\
\text { receive enough }\end{array}$ & 9 & Yes & 20.5 \\
$\begin{array}{l}\text { remuneration as } \\
\text { motivation from their } \\
\text { organization? }\end{array}$ & 35 & No & 79.5 \\
$\begin{array}{l}\text { Can sport coaches } \\
\text { performance without } \\
\text { remuneration? }\end{array}$ & 5 & Yes & 11.4 \\
$\begin{array}{l}\text { Is remuneration a factor } \\
\text { influencing the } \\
\text { motivation of sports }\end{array}$ & 41 & No & 88.6 \\
coaches? & 3 & Yes & 93.2 \\
\hline
\end{tabular}

Majority of the respondents coaching status indicated that $16(36.3 \%$ are grade I coaches, $8(18.2 \%)$ were grade II coaches, $8(18.2 \%)$ were grade III coaches while $12(27.3 \%)$ of the coaches falls under para-coach which were also served as assistant coach or coaching assistants. It was also seen that about $21(54.6 \%)$ of the respondents coached team sports, 6 $(13.6 \%)$ coached dual sports while $14(31.8 \%)$ of the respondents coached individual sports.

Table 2 above showed that $9(20.5 \%)$ of the respondents indicated Yes, while 35 (79.5\%) said no that coaches do not receive enough remuneration as motivation from their organization. In the same table, $5(11.4 \%)$ of the respondents indicated that sports coaches cannot perform well without remuneration. Majority of the respondents indicated a contrary that $39(88.6 \%)$ were not in support of the statement, therefore, their answer indicated no against the statement. It was also discovered that remuneration is a factor influencing the motivation of sports coaches as indicated on the table with 41 $(93.2 \%)$ of the respondents agreed while only $3(6.8 \%)$ minority of the respondents were against the statement.

Table 3. Respondents' views on perception of coaches on education / training $(n=44)$.

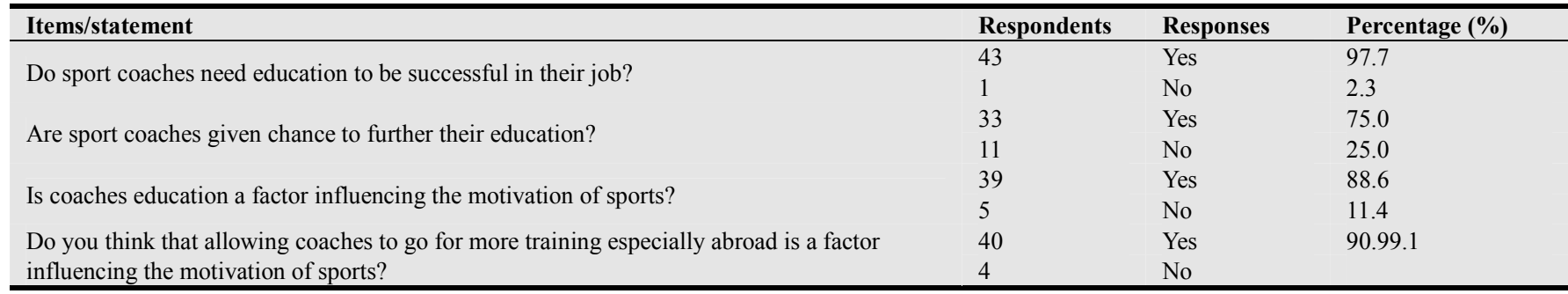

Table 3 above indicated the results that $43(97.7 \%)$ of the respondents were of the opinion that sports coaches need education (more knowledge) to be successful in their job, whereas only $1(2.3 \%)$ of the subjects said no. it was also observed on the same table that about $33(75 \%)$ of the respondents were in support of the statement that sports coaches should be given chances to further their education so that to update their knowledge on coaching. While few respondents $11(25 \%)$ indicated no with the statement. Similarly, the table shows that $39(88.6 \%)$ of the respondents were of the opinion that coaches adequate knowledge on their job is necessary so that it can influence the motivation of their coaching career. Whereas only few of the respondents $5(11.4 \%)$ said a contrary view. In the same table $40(90.9 \%)$ of the respondents being majority agreed with the statement of sports coaches should be sponsored to obtain more knowledge / qualification or training abroad in order to motivate them. Only few of the respondents 4 (9.1\%) were not in support of the statement.

Table 4. Respondents views on the availability of facilities / equipment $(n=44)$.

\begin{tabular}{|c|c|c|c|}
\hline Items/statement & Respondents & Responses & Percentage (\%) \\
\hline \multirow{2}{*}{ Are there enough facilities for sports coaches to carry out their activities successfully? } & 4 & Yes & 9.1 \\
\hline & 40 & No & 90.9 \\
\hline \multirow{2}{*}{ Is availability of facilities / equipment a factor influencing the motivation of sports coaches? } & 43 & Yes & 97.7 \\
\hline & 1 & No & 2.3 \\
\hline \multirow{2}{*}{ Can facilities without standard equipment help sports coaches to carry out their activities successfully? } & 1 & Yes & 2.3 \\
\hline & 43 & & 97.7 \\
\hline $\begin{array}{l}\text { Are standards equipment / facilities used served as a factor influencing the motivation of sports } \\
\text { coaches? }\end{array}$ & 44 & Yes & 100 \\
\hline
\end{tabular}

Table 4 above indicate the results that majority of the respondents $40(90.9 \%)$ did not agreed that there were no enough facilities for the sports coaches to carry out their activities successfully, while only few of the respondents 4 (9.1\%) said a contrary view. Whether the availability of the facilities / equipment is a factor influencing the motivation of sports coaches, the higher number of the respondents 43 $(97.9 \%)$ were of the opinion that available facilities / equipment determine the motivation of sports coaches while only $1(2.3 \%)$ said no on the statement. Similarly, the table showed that majority of the respondents were of the opinion that facilities without standard cannot influence the motivation of sports coaches which constituted of 43 (97.7\%) while only 1 person said a contrary view. Therefore the use of standard equipment and facilities determined the motivation of sports coaches with $100 \%$ of the respondents indicated their views on the statement. 


\section{Discussion}

This study determined factors influencing the motivation of sports coaches in the organizational and management of sports competition in Owerri municipal council of Imo state. The findings of the study indicated that remunerating sports coaches influenced their motivation in the organization and management of sports competitions. This is in line with the findings of Nwachukwu (2007) that a satisfied employee (coaches) has a better attitude to work than a dissatisfied employee. In support of this Longe (2008) opined that remunerating and condition of service also affect occupation. Similarly, Harry (1999) made a very interactive observation about an unpaid employee, where he pointed out that the characteristic of a Jackass are tamed as stubbornness, stupidity, will-fullness and unwilling to go to where someone is driving him. These by interacting coincidence are also characteristics of the unpaid employee. No efforts should be speared by management to ensure that remuneration necessary for sports coaches are made available. The findings also showed that majority of the respondents indicated that updating coaches knowledge or additional qualification is a factor influencing the motivation of sports.

In line of this, Pestolesi (1978) suggested that administrators should workout plans for in-service education opportunities for coaches and other staffs. In support of this, Lyle Alison and Taylor (1997) stated in their studies that 85\% of coaches in Scotland said that the availability of grants for courses and training would be important in sustaining their interest. Therefore, special consideration needs to be given to the provision and delivery of coaches education and training. Grants should also be made available to assist targeted coaches particularly to attend refresher courses, conferences, seminars and visiting expert programme on sports organization and management/. The result also revealed that $100 \%$ being majority of the respondents agreed that availability of facilities with standard equipment determined the influencing factor in the motivation of sports coaches in the organization and management of sports competition. In line with this, Nwachukwu (2007) asserted that, the type of technology used in an organization influences employee productivity. In support of this, Warner (2009) opined that the kind of standard facilities and equipment found in Nigeria stadia were satisfied for the hosting of Nigeria 2009 FIFA under 17 world cup. The use of standard facilities and equipment in both training and competition has serious impact on athletes (users). Therefore government / organizations should provide facilities with standard equipment to enhance coaches innovative approaches.

\section{Conclusion and Recommendations}

Based on the result and in view of limitation of this study it was concluded that remuneration, in-service, education and the availability of standard facilities and equipment should be identified in order to influence the motivation of sports coaches in the organization and management of sports competitions in Owerri municipal Council, Imo State. Based on this conclusion, therefore, it is recommended that effort should be made by management to ensure that remuneration necessary for sports coaches available and in good time. Provision of grant schemes, scholarship, general promotion of coaching and a comprehensive education system are essential but efforts should also be created and supported a positive working environment for coaches must be a long term priority. Administrators should also make plans to assist targeted coaches particularly to attend refresher courses, conferences, seminars to update their knowledge on the coaching profession.

\section{References}

[1] Adeniyi, K. (2009). Nigerian Television Authority, Nationwide Sports Report.

[2] Bucher, C. A. \& Thaxton, N. A. (1981). Physical Education and Recreation, Sports Change and Challenges, St. Louis, the C. V. Mosby Company.

[3] Butt, D. S. (1974). Psychological motivation in Sports, California National Press Books.

[4] Chantal, J. Guay, S. O., Debreva, M. \& Vallerand, C. (1996) Coaching strategies; The influencing of a motivation in Sports Promotion. California State University.

[5] Charbonneau, D. Barling, J. \& Kelloway, E. K. (2001). Transformational leadership and sports performance.

[6] Deci, T. S. \& Ryan, M. (2002). Coaches and cohesion. The impact of coaching techniques on team cohesion in the small group setting; Journal of Sports behaviour, (20), 86-104.

[7] Department of National Heritage (1995). Department of Excellence in Sports.

[8] Hansen, B. Gilbert, W. Hamel, T. (2003). Successful coaches' views on motivation and motivational strategies. The Journal of Physical Education, Recreation and Dance, (74), 45-48.

[9] Harry, L. (1999). Attitude towards motivation. Harvard Business Review; (5), No. 1, 70-76.

[10] Longe, P. (2008). Lecture notes on Administration and remuneration of coaches job satisfaction in Oyo State Sports Council, Nigeria.

[11] Lyle, J. Allison, M. \& Taylor J. (1997). Factors influencing the motivation of sports coaches. Research report No. 49; A research study for the Scotland Sports Council.

[12] Miller, D. M. (1974). Coaching the female athlete, Philadelphia \& Febiger.

[13] National Coaching foundation (1993).

[14] Nwachukwu, C. C. (2007). Supervision and productivity in Nigeria; organization. The journal of Management studies, University of Ghanna (2), Vol. 1. 48-60.

[15] Opatola, G. O. (1999). Sports coaching and competition, St. Andrew's College of Education Oyo. 
[16] Okoye, N. N. (1987). Psychology of learning: A University Lecture text, published by the University of Ibadan, IBADAN, Nigeria.

[17] Perisgard, A. M., \& Roberts, G. C. (2002). Elites Athletes experiences motivational climate. The coach mallers. Scandinavian Journal of Medicine in Sports. Vol. 12 54-59.

[18] Pestolesi, R. A. (1978). Creative Administration in Physical Education and Athletics

[19] Singer, W. R. (1997). Motivation in Sports; International Journal of Sports Psychology, p. 1-22.
[20] The publication of coaching matters (coaching review panel, 1991).

[21] Vallerand, A. \& Thrill, S. A. (1993). Coaching strategies used to motivate athletes; Journal of Sports behaviour p. 18.

[22] Warner, J. (2009). FIFA Vice President's visit to Nigeria for the hosting of under 17 World Cup.

[23] Weinner, B. (1992). Theories of motivation from mechanism of cognition. Chicago Rand Mcnally. 